\begin{tabular}{|l|c|c|c|c|}
\hline $\begin{array}{l}\text { Cuadernos de Investigación Geográfica } \\
\text { Geographical Research Letters }\end{array}$ & 2020 & N $^{\circ} 46(2)$ & pp. 477-496 & eISSN 1697-9540 \\
\hline
\end{tabular}

\title{
EROSIVE FEATURES CAUSED BY A MAGELLANIC PENGUIN (SPHENISCUS MAGELLANICUS) COLONY ON MARTILLO ISLAND, BEAGLE CHANNEL, ARGENTINA
}

\author{
D.R.A. QUIROGA ${ }^{1,2 *}$, A. CORONATO ${ }^{1,2}$, G. SCIOSCIA ${ }^{1}$, \\ A. RAYA REY ${ }^{1,2}$, A. SCHIAVINI ${ }^{1,2}$, J. SANTOS-GONZÁLEZ ${ }^{3}$, \\ C.R. LÓPEZ ${ }^{1}$, J.M. REDONDO-VEGA ${ }^{3}$
}

\begin{abstract}
${ }^{1}$ CONICET-CADIC, B. Houssay 200 (9410) Ushuaia, Argentina. ${ }^{2}$ ICPA-UNTDF, Walanika 250 (9410) Ushuaia, Argentina. ${ }^{3}$ Dpto. de Geografía y Geología, Universidad de León, Campus de Vegazana, s/n, 24071 León, España.
\end{abstract}

\begin{abstract}
An active Magellanic penguin (Spheniscus magellanicus) colony has been established on Martillo Island, Beagle Channel (54 54'26" $S ; 67^{\circ} 22^{\prime} 58^{\prime \prime} W$ ) since 1976. It is located in remnants of eroded drumlins placed in both ending and joined by gravel terraces of glaciofluvial and marine origin. Forest patches occupy the eastern side of the island while most of the island is covered by bushes, tussocks and grasses. This paper presents penguins as bio-erosion agents on glacial and marine landforms. An analysis of multiple criteria surveyed in the field was performed, using Quantum GIS ${ }^{\circledR}$ 3.2.1 with remote sensing images and a digital model terrain of $12 \mathrm{~m}$ resolution. The morphometric data and multicriterial evaluation were collected during 2016-2017 austral summer. Soils and sediments of each landform (drumlin, glaciofluvial terrace, raised beach and beach) were sampled for particle size analysis, to determine if there is any relationship between the morphometric parameters of the cave and the sediments. Four bio-erosion classes were defined based on the erosion features observed in the field. "Moderate" was the prevailing erosion class recorded, in the E-NE part of the island. Bioerosion features are mainly developed on the $N$ facing slope of the east of the island, where a natural gully drains rainfall water, and over the glaciofluvial and marine terrace surfaces. Erosive features such as caves and bridges are mainly developed in silty drumlins. Pedestals are developed on bare soils and tussocks. Trails and cracks were also described as bio-erosion. No erosive features were recorded in the W part of the island. The bio-erosion map is one of the inputs for environmental degradation analysis and population dynamic research which is being done in the Magellanic penguin colony on Martillo Island, Beagle Channel.
\end{abstract}


Rasgos erosivos causados por una colonia de pingüinos magallánicos (Spheniscus magellanicus) en la Isla Martillo, Canal Beagle, Argentina

RESUMEN. Desde 1976 en la Isla Martillo (Canal Beagle, 5454'26” S; 67²2’58” O) se asienta una colonia de pingüinos de Magallanes (Spheniscus magellanicus). Alli se identifican geoformas de origen glacial y marino, entre las que se destacan: drumlin, terrazas glacifluviales y marinas, y playas. La vegetación de la isla está compuesta por fragmentos bosque localizados mayoritariamente en el E de la isla, y la superficie restante está cubierta de arbustos, matas y pastos. Este trabajo presenta a los pingüinos como agentes erosivos en las geoformas terrestres, glaciares y marinas. Se realizó una evaluación multi-criterio de relevamiento de campo. La geo data base se trabajó en el entorno GIS Quantum GIS ${ }^{\circledR}$ 3.2.1, utilizando imágenes satelitales y un modelo digital del terreno (MDT) de $12 \mathrm{~m}$ de resolución espacial, como base de referencia visual. Los datos morfométricos y la evaluación multi-criterio se recopilaron durante el verano austral 2016-2017. Se tomaron muestras de los suelos y sedimentos de cada forma de relieve (drumlin, terraza glacifluvial, playa elevada y playa) para analizar el tamaño de partícula, para determinar si existe alguna relación entre los parámetros morfométricos de la cueva y los sedimentos. Se definieron cuatro clases de bioerosión en función de las características de erosión observadas en el campo. "Moderada" fue la clase de erosión predominante, en la parte E-NE de la isla. Los rasgos erosivos se desarrollan principalmente en la ladera con orientación $N$ del E de la isla, donde un barranco natural drena el agua de lluvia y sobre las superficies de las terrazas glacifluviales y marinas. Las características erosivas como las cuevas y los puentes se desarrollan principalmente en drumlins limosos. Los pedestales se desarrollan en suelos desnudos y matas. Los senderos y las grietas también se describieron como bioerosión. No se registraron características erosivas en la parte oeste de la isla. El mapa de bioerosión es uno de los insumos para el análisis de degradación ambiental y la investigación dinámica de la población que se está realizando en la colonia de pingüinos de Magallanes en la isla Martillo, Canal Beagle.

Key words: Magellanic penguin, erosive features, zoogeomorphology, Martillo Island, Beagle Channel.

Palabras clave: pingüino magallánico, formas erosivas, zoogeomorfología, Isla Martillo, Canal Beagle.

Received: 16 August 2019

Accepted: 30 December 2019

*Corresponding author: Diego Rubén A. Quiroga, CONICET-CADIC, B. Houssay 200 (9410) Ushuaia, Argentina. E-mail address: diegoquir@cadic-conicet.gob.ar

\section{Introduction}

Zoo-geomorphology studies the role of faunal organisms as a geomorphological agent (Butler, 1995). Different animal species have a relevant influence in geomorphic 
evolution, resulting in landforms creation and sediment removals (Butler and Hill, 1992; Borchard and Eldridge, 2011; Eldridge et al., 2012; Jones, 2012; Combes and Viles, 2015; Haussmann, 2017). The action of animals interacts with other geographic variables, contributing to increasing erosive processes (e.g. Tricart, 1977; Hall and Lamont, 2003).

Magellanic penguins (Spheniscus magellanicus) are found in both the Pacific and the Atlantic Ocean and nest along the coasts of Argentina and Chile. Breeding colonies are found along the $\mathrm{S}$ coast of South America: from Pájaro Niño Islet $\left(33^{\circ} 21^{\prime} \mathrm{S}, 71^{\circ} 41^{\prime} \mathrm{W}\right)$ on the Pacific Ocean to Redondo islet $\left(41^{\circ} 26^{\prime} \mathrm{S}, 65^{\circ} 01^{\prime} \mathrm{W}\right)$, including the Malvinas (Falkland) Islands, and Staten Island in the Atlantic Ocean and the Martillo Island in the Beagle Channel (Williams 1995; Gandini et al., 1996; Schiavini et al., 2005). Magellanic penguins (Spehniscus magellanicus) aggregate seasonally in dense colonies to breed and return each year after winter dispersal. At Martillo Island, Magellanic penguins arrive in early September to build, repair and occupy their nests, to begin courtship and pair formation. Males and females take shifts to incubate eggs and feed chicks between October and February (Boersma et al., 1990), switching almost daily between their nests and the sea (Scioscia, 2011; Raya Rey et al., 2012; Scioscia et al., 2016). The juveniles, born the previous breeding season, arrive at the colony during January and leave the colony by late February, together with the fledged chicks from that breeding season. Finally, adults moult before leaving the colony between late March and early April.

During 2005-2006 season Santos Gonzalez et al. (2006) performed the first observation of the erosive effect of Magellanic penguin at Martillo Island. Nest building favours the progressive deterioration of vegetation cover and soil, sediment loss as well as coastal micro-topography modification by digging and trampling. Magellanic penguins build three different nest-types: nests under bushes, burrow nests and open scrapes (Boswall and MacIver, 1975; Stokes and Boersma, 1998) lining nests with local resources as soil, fine sediments, sand, gravel, long grass leaves and branches of bushes. In colonies developed in temperate-cold climate environments, the vegetation and soil recovery of the growing season is not enough to avoid the erosion that intensifies during each penguin breeding season, when the penguin transit and occupation of the island intensifies.

Substrate conditions for Patagonian penguin colonies development have been addressed by Gandini (1993), Stokes and Boersma (1991, 1998), García-Borboroglu et al. (2002) from an ecological point of view. Grain size, textural conditions, slope, air temperature, precipitation, vegetation-type, nest exposure and distance to the coast distance described as factors affecting reproductive success, nest density, predation and survival. In addition, Ercolano et al. (2016) showed that desertification and coastal archaeological heritage damage increased by the penguin's activity. The penguin action interacts with other geomorphological agents, contributing to explain landforms evolution (Hall and Lamont, 2003). The processes involved varies depending on the climate, geological and topographic conditions, but in Martillo Island, aeolian and coastal processes are the most relevant.

This paper analyses the erosive effect of Magellanic penguins in relation to nest density on the local relief and sediment removal at one of the Beagle Channel Islands 
$\left(\sim 54^{\circ} 55^{\prime} \mathrm{S}\right)$. A typology of erosive features over glacial and littoral landforms as a result of digging and trampling is herein presented. The species is proposed as a strong geomorphic agent with bio-erosion capabilities.

\section{Study area}

Martillo Island extent over 44 ha at $54^{\circ} 54^{\prime} \mathrm{S}-67^{\circ} 22^{\prime} \mathrm{W}$ in the central part of the Beagle Channel. Its W-E axis is parallel to the channel and it is $1.2 \mathrm{~km}$ long while the N-S axis is $0.64 \mathrm{~km}$; the maximum elevation is $37 \mathrm{~m}$ a.s. 1 . It is part of a drumlin field flooded by marine waters since the Early Holocene. Drumlins were generated during the Last Glacial Maximum by the Beagle paleoglacier, which flowed eastwards from the Darwin Cordillera, in the Chilean Fuegian Andes (Rabassa et al., 2000). Radiocarbon dating on marine shells revealed that marine waters started to flood the glacial landscape ca. $8 \mathrm{ka}$ BP from from the Murray Channel, located $50 \mathrm{~km} \mathrm{~W}$ of the study area $\left(54^{\circ} 56^{\prime} 55^{\prime}\right.$ S $\left.-68^{\circ} 23^{\prime} 11^{\prime \prime} \mathrm{W}\right)$ (Rabassa et al., 1986, 2009; Gordillo et al., 2002). Another hypothesis suggests that the marine waters flood could occur simultaneously from the E, once the seawater overpass the former scarp, now a talus, between the glacial through and the marine floor and flooded westwards along the valley (Bujalesky et al., 2008). The higher drumlins relative relief than the valley bottom avoids their complete immersion and transformed them in islands as Gable, Yunque, Martillo and the minor ones (Fig. 1), while inter-drumlin depressions became in embayments between the minor and the main channels (Isla et al., 1999). Raised beaches have been recognized in the $\mathrm{N}$ coast of this part of the channel. These are formed by medium discoidal and rounded gravel, sand and sub-fossil marine shells deposited during the Late Holocene marine high standings (Bujalesky et al., 2004). Due to its similarity in elevation and composition, these could be of similar age of those of Martillo Island.

The island climate is temperate-cold oceanic (Coronato et al., 2008). The mean annual temperature is $5^{\circ} \mathrm{C}$, the thermic amplitude is low, precipitation is $650 \mathrm{~mm} /$ year and regularly distributed along the year, regular snowfall is from May to September, but with occasional summer snowfalls. Westerly's blow regularly from the SW but winds from the $\mathrm{N}$ quadrant also occur generating warm and dry air conditions. Wind direction and precipitation gradients are conditioned by the surrounding orographic barriers. The vegetation of the island is represented by species of Sub Antarctic Mixed Forest as Nothofagus Antarctica (Antarctic Beech), Magellan's Mayten or Maytenus Magellanicus (leña dura), Winter's bark or Drymis Winterii (canelo), and Embothrium Coccineum (notro), as well as bushes of fashioned or Chillotrichum Diffusum (mata negra), Berberis Buxifolia (calafate), Hierochloe Redolens and species introduced as Capsella Bursapastoris and Rumex sp. (lengua de vaca) are common. Hepatics, mosses and pillowvegetation appear in deteriorated soils.

Martillo Island is a breeding site for several seabird species, with the Magellanic penguin (Spheniscus magellanicus) the most abundant (Schiavini and Raya Rey 2001; Raya Rey et al., 2014). The colony has been reported on the island, at least since 1976 (Schiavini and Yorio, 1995). In 1992 the breeding population 
was estimated in 519 breeding pairs (Schiavini and Yorio, 1995), and the breeding population increased ca 15\% in 20 years (Raya Rey et al., 2014). At Martillo Island, the three types of nests are present, but the majority are caves $(59 \%$, Schiavini et $a l .$, unpublished data). Magellanic penguins build their nests in burrows digged by themselves, or under bushes, as well as over depressions in the ground (Boswall and MacIver, 1975; Schiavini et al., 2005).

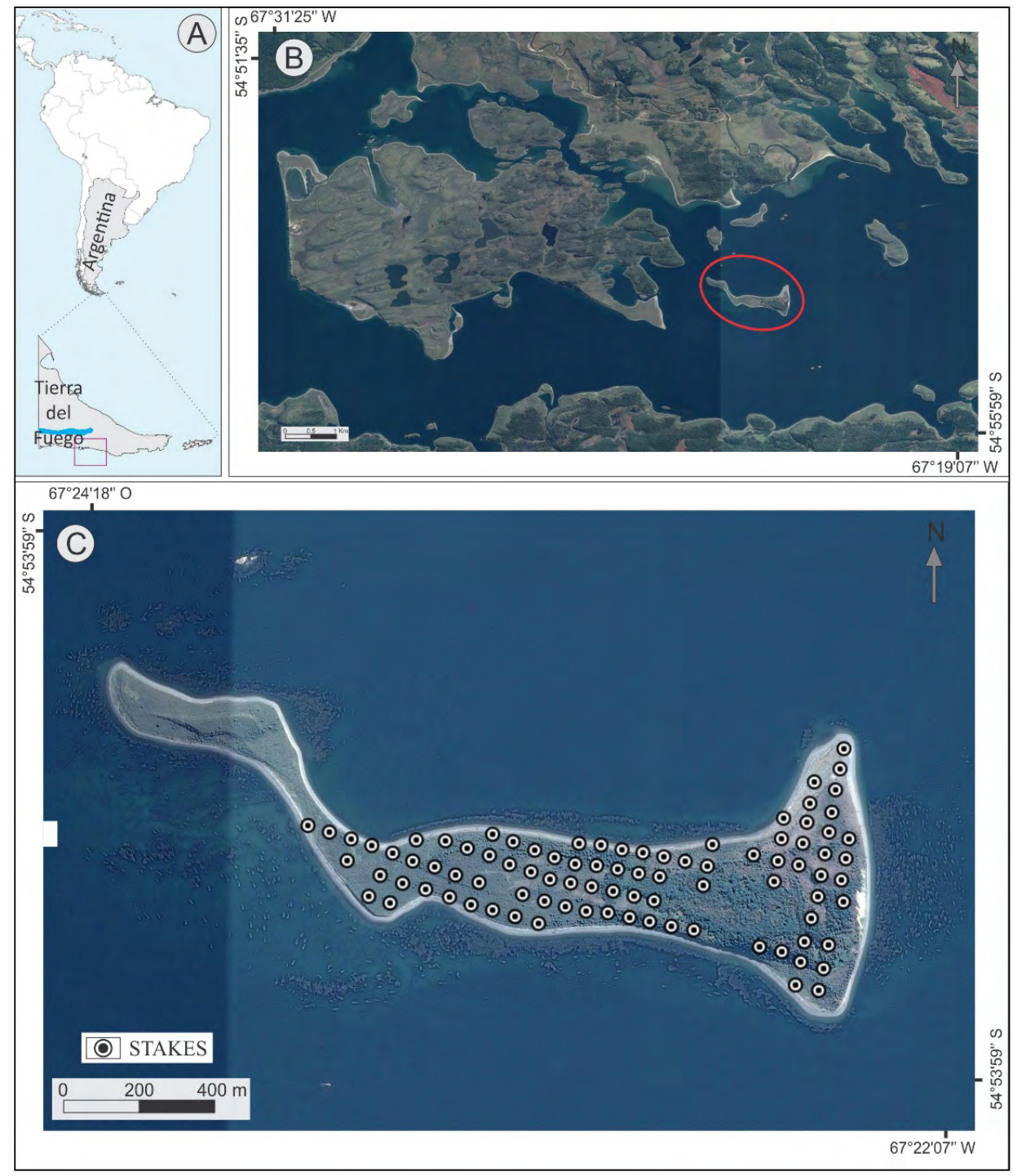

Figure 1. Martillo Island location. A) Southern Argentina, South America; B) Martillo Island location in the Beagle Channel C) Martillo Island. Base image: Google Earth ${ }^{\circledR}$. 
The island belongs to the nearby Estancia Harberton. The main activity until the end of the $20^{\text {th }}$ century was extensive sheep ranching. Martillo Island was used to hold mutton sheep until about 1960. In the last years, the main activity of the ranch became tourism, and visits to Martillo Island are the main attraction. Tours to the island are restricted and managed by the ranch under recommendations made by CADIC (Centro Austral de Investigaciones Científicas) specialists.

\section{Materials and methods}

Field recognition and mapping of topography, landforms and geomorphic processes were surveyed based on a coordinate grid of numbered stakes separated $50 \mathrm{~m}$ from each other (Fig. 1).

The nest density (Dn: nests/ha) was estimated at each point of a permanent grid (the same points, stakes, used for erosive features measurements) using the point-transect methodology (Raya Rey et al., 2014) during each breeding season since 2004 to 2016 years. Analyses were carried out using Distance 7 Release 1 (Thomas et al., 2010). Then, the average nest density between 2004 and 2015 years was calculated by stake and extrapolated to the entire colony area by means of the triangulation and interpolation of the values by point.

A GIS database was created in QGIS 3.2.1 platform. Google Earth ${ }^{\circledR}$ models and imagery complemented with the Open Layer Plug-in were used for image view and screen digitalization. Once the geodatabase was compiled, the records were interpolated and triangulated in order to have a complete cover of variables on the entire island.

The slope was estimated using the slope tool of QGIS 3.2.1 Bonn, using a reference base of the DEM, ALOS PALSAR DEM, and spatial resolution $12 \mathrm{~m}$ (USGS-NASA). The slope is in 5 equal intervals. The value of the slope was obtained by date and was used as an input for the development of the generalized linear models (GLM).

The effect of average Dn, slope and type of sediment on the erosion percentage were analysed using generalized linear models (GLM) with a Quasi-binomial distribution of errors and log it link function.

Altimetry data were recorded using an ALOS PALSAR, with 12 m of the resolution, which was then improved to $10 \mathrm{~cm}$ with Trimble R8x measurements. This survey allowed to correct the model distortions in low relief and close to the sea level. Topographic profiles were calculated with the elevation model data along cross-sections, from the $\mathrm{S}$ to the $\mathrm{N}$ coasts in $\mathrm{W}$, middle and east sectors of the island.

The morphometric data and multicriteria evaluation were collected during 2016-2017 austral summer. Erosion variables and landform-types were recorded and measured in some stake $(80 \%)$ or observation point. Caves used as burrownests, bridges, cracks, pedestals and trails were recognized as erosion features on landforms. A multiple criteria analyses were later applied to obtain the bio-erosion map. For this purpose, presence or absence of erosive features was weighted as 1 or 0 
respectively, then the sum of the present features (those with 1) gave erosion values for each observation point. These values range from 1 to 15 suggesting low or high erosion conditions, respectively. A weighting was carried out according to the criteria of the author of the variables in order to obtain homogeneous values. More weight was given to cases where bridges existed compared to cracks. It was also considered as an evolutionary feature of erosion when the roads were larger than $10 \mathrm{~cm}$ and without vegetation. Finally, the cases in which the pedestals were greater than $10 \mathrm{~cm}$ were revalorized. These values were later transformed to erosion percentage categories, through the use of the rule of three. It was grouped into categories according to erosion degree Low (0-30\%), Medium erosion (30-50\%) Medium-high erosion (50-70\%) and High erosion (more than $70 \%$ ).

Thirteen samples of the sediment taken from different geomorphological units were analyzed: Beach (2), Raised Beach (4), Drumlin (4) and Glaciofluvial terrace (3). A-axis fabrics of 50 clasts per deposit were realized in the two drumlins. Elongated clasts (long to intermediate axis ratio $>1.5)>10 \mathrm{~cm}$ were chosen because they are similarly oriented to glacier flow and lead to a consistent fabric (Benn and Evans, 1996). Samples were taken in natural exposures. Data were plotted and contoured in equal-area nets. These representations provide information on the nature of the fabric that could be isotropic (no main direction), girdle points distributed around a circle, or cluster (most of the A-axes clasts show the same orientation). Grain-size analyses were performed for each landform type. Rotation sieve stacks and laser analyser Mastersizer 2000E were used at CADIC laboratory.

A subsampling of the caves was carried on to analyses the relationship between height $(\mathrm{X})$ and width $(\mathrm{Y})$ of the cave mouth $(\mathrm{R}=\mathrm{X} / \mathrm{Y})$ as a proxy for the cave mouth morphology. The subsampling was performed at random, surveying 5 caves per stake.

Principal components analysis (PCA) was performed with the type of sediment as the variables to describe the composition of different landforms.

A one-way ANOVA was made to compare the X, Y, Z measurements of the caves made by the penguins among the different landforms. The normality and homoescedastic assumptions were verified by means of QQ plot of the residues and Shapiro-Wilks tests and the analysis of the residues and predicted, respectively.

Statistical analyses were performed using Info Stat software (Di Rienzo et al., 2009) and R software, Version 3.4.4 (R Development Core Team 2009).

\section{Results}

\subsection{Nests density and distributions}

The breeding population size of Magellanic penguin at Martillo Island in 2016 was 4876 breeding pairs (confidence intervals 95\% 3985-5936). The largest average nest density (between 2004 and 2015 years) was found in the eastern part of the island (Fig. 2). 


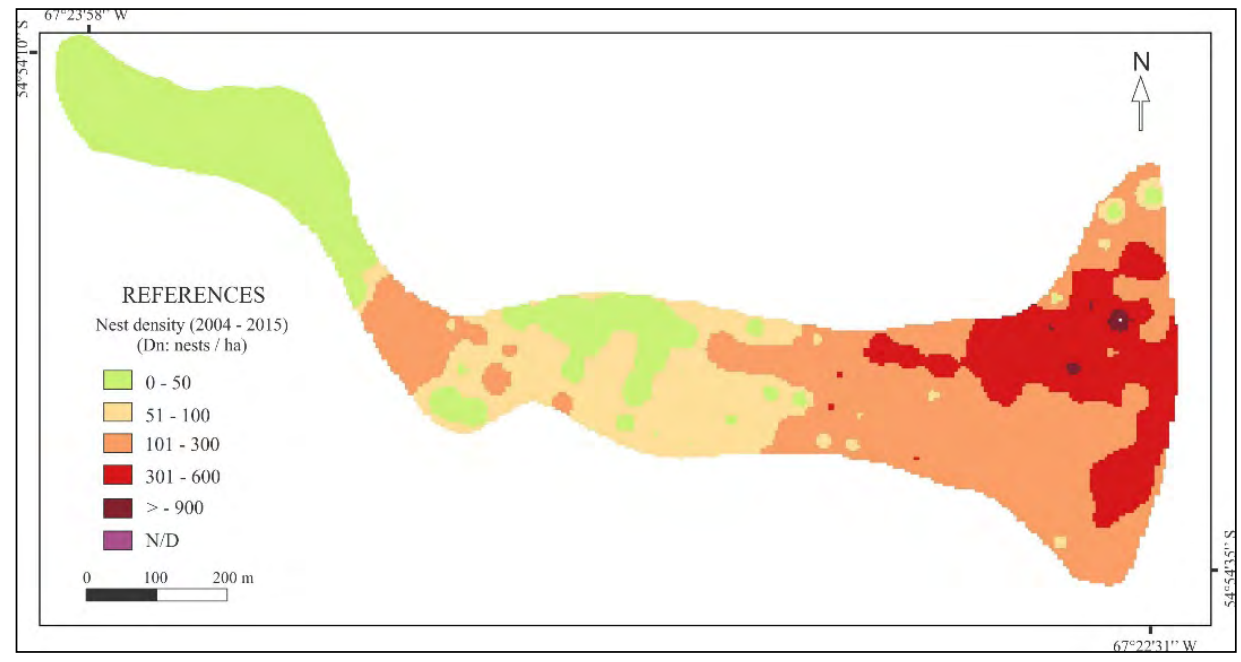

Figure 2. Average nest density in Martillo Island on 2004-2015.

The western area had a very low density of nests or no nest at all. The maximum density (950 nests/ha) was found NE of the island, near the area visited by tourists. An estimation of the total number of penguins that Martillo Island hosts must take into account the breeding pairs, the non-breeding adults, juvenile and chicks. As juvenile and non-breeding adults can spend most of their time at sea, the best proxy for the number of birds at Martillo island during the breeding season of 2016, sums up at least 19,408 individuals, composed by 9800 breeders, 6762 fledged chicks from a breeding success of 1.38 (SD: $0.85 ; \mathrm{n}: 224$ ) fledged chicks per nest, and 2847 juvenile per year assuming a mortality is $57.9 \%$ during first pelagic migration (Scolaro, 1980, own data).

\subsection{Topography and geomorphology}

The island is formed by two asymmetric hills located in the $\mathrm{W}$ and $\mathrm{E}$ ends joined by almost flat and different level terrains. It is irregular in shape (Figs. 1B and C) with an increasing surface eastwards. The interior has low slopes $(4.3 \%$ a $7.9 \%)$ while along the eastern cliffs, in the NW and SE coast paleocliffs present the maximum slope values (15\%). In the rest of the island, the coast is low with beach slopes of less than $1 \%$ (Fig. 3).

Four types of landforms were identified: Drumlins, Glaciofluvial terraces, Raised Beaches and Beaches (Fig. 4). Drumlins and glaciofluvial terraces represent the ancient glacial landscape. Eroded drumlins are located in both island ends, and together they occupy the $36 \%$ of the island surface. The higher elevation ( $31 \mathrm{~m}$ a.s.1., $15 \mathrm{ha}$ ) is at the eastern end. It has the typical drumlin asymmetrical slope. Due to long-term evolution, the original form is transformed, showing a relative soft side to the east and a leeward slope cut by the action of the western waves, generating a cliff where glacial deposits are visible. This cliff is a barrier to the transit of penguins. 


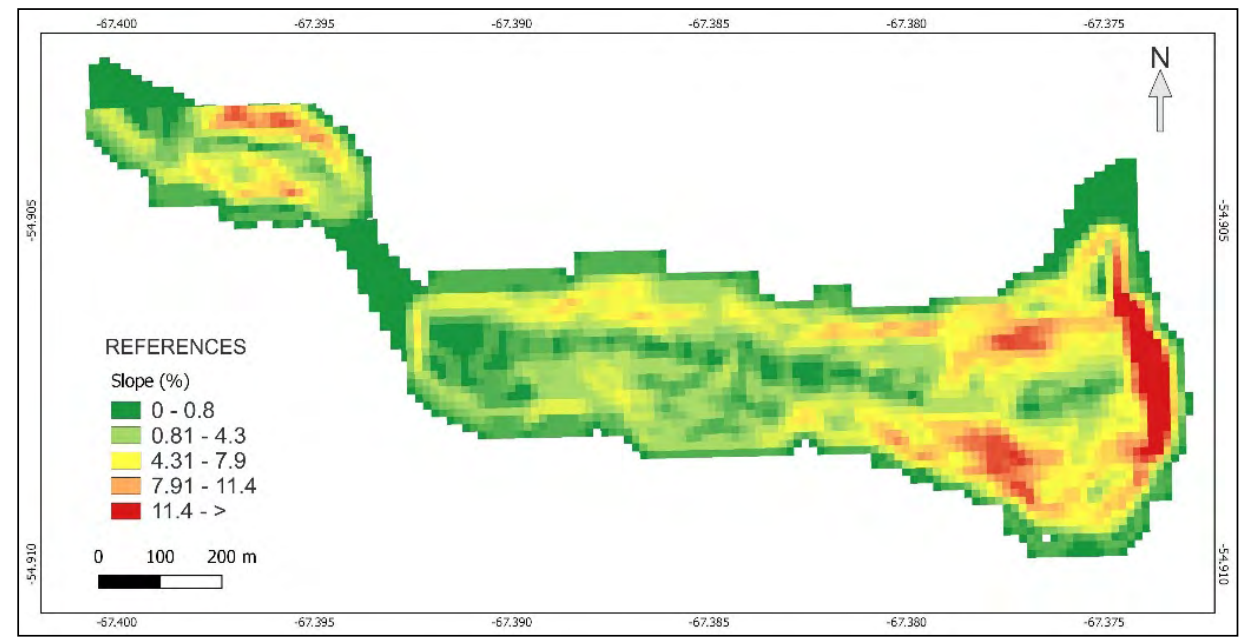

Figure 3. Slope map (in percentage) of Martillo Island, Beagle Channel.

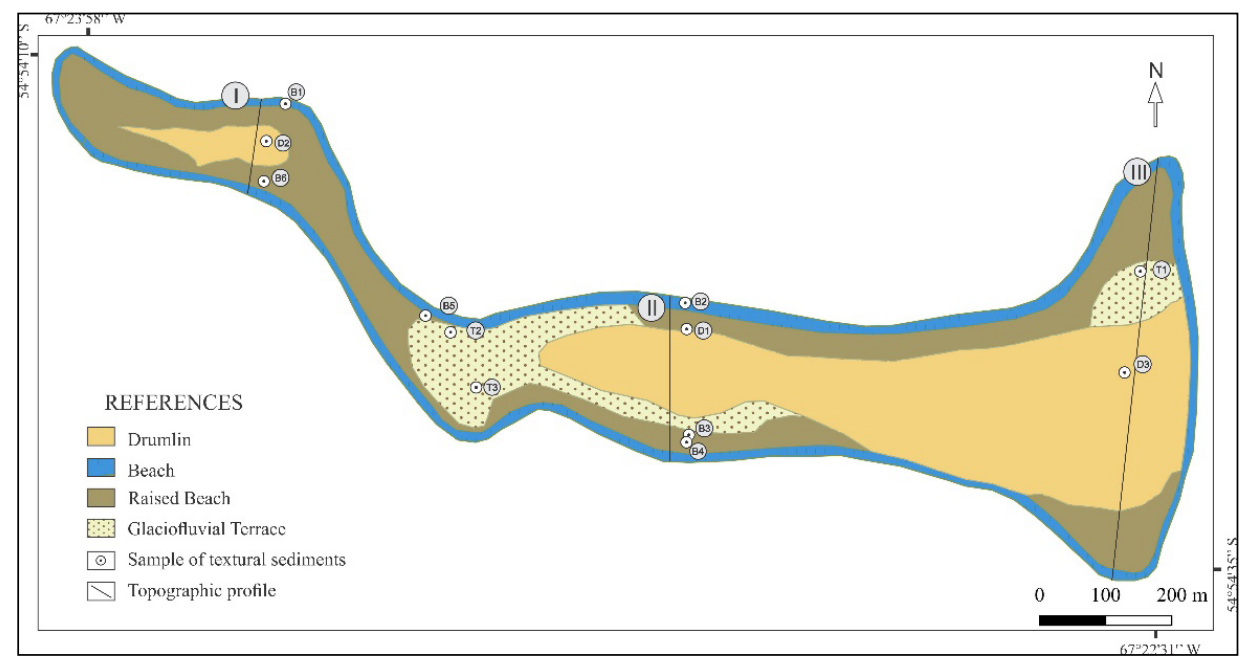

Figure 4. Landforms distribution in Martillo Island, Beagle Channel. The line represents the topographic profiles transects across Martillo Island, South-North direction. I) Western ending, II) center and III) eastern ending. D1, 2, y 3 = Sample of textural of drumlin; T1, 2, y 3 = Sample of textural of Glaciofluvial Terrace; B1, 2, 3, 4 y 5 = Sample of textural of Beach and Raised beach.

The asymmetry in its long axis is reinforced by wave action and mass-wasting in the down-ice side. A transversal slope varies in both drumlins (Figs. 5B and C). The western drumlin (1 ha, $7 \mathrm{~m}$ a.s.1.) lost its original shape by littoral erosion and deposition during high standings sea-level, probably during the Late Holocene (Fig. 
5A). Till fabric analysis show that clasts in the main drumlin are well oriented to the main paleo-ice flow direction $\mathrm{W}-\mathrm{E}$ and show a small range in dip/plunge values. In the small drumlin, clasts have a similar distribution but tend to be oriented SW to $\mathrm{NE}$, suggesting that the still visible of the drumlin corresponds to its $\mathrm{N}$ sector. Its sedimentary composition is basal till, made by a sandy-silt matrix, with very low clay fraction proportion and gravels of different lithologies (Fig. 6). These two landforms and the others in the surrounding islands and in the bottom channel are the source of gravel for beaches formation.

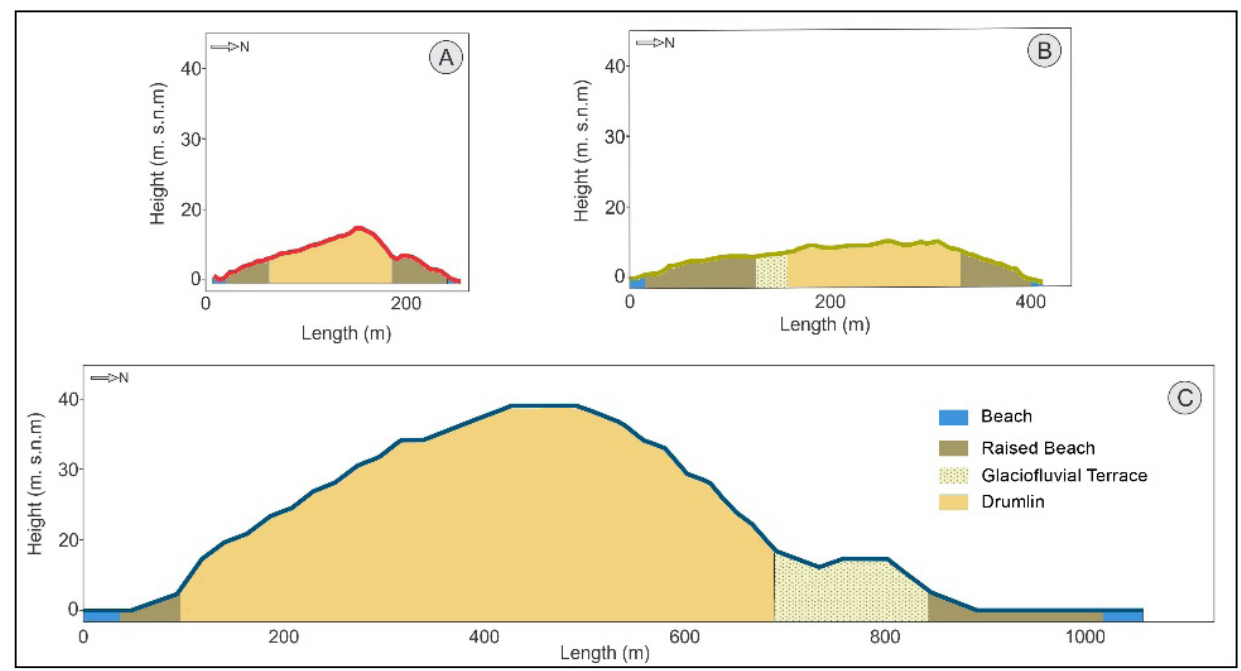

Figure 5. Topographic profiles across Martillo Island, $S$ - $N$ direction. They were made using $12 \mathrm{~m}$ resolution DEM. A) western ending, $B$ ) center and $C$ ) eastern ending. The location on the island is seen in Figure 4.

Glaciofluvial terraces develop surrounding the bigger drumlin by the $\mathrm{N}, \mathrm{W}$ and S (Fig. 4). They are placed at 6 to $8 \mathrm{~m}$ a.s.1. and occupy the $11 \%$ of the island surface. Most of them have low slopes with a short scarp to the raised beaches upper levels. The exception is the unit located in the northern area, which stands $5 \mathrm{~m}$ over the raised beach. Their sedimentary composition is slightly variable (Fig. 6). While the lowest and western terraces are mainly gravelly with low content of sands and silts, the highest terrace is composed of sands in all grain-sizes and lower content of gravels than in the others. Gravel is rounded as a result of fluvioglacial transport and deposition along the inter-drumlin depressions during the general Beagle paleoglacier recession towards the $\mathrm{W}$, probably during the Late-Glacial times. 


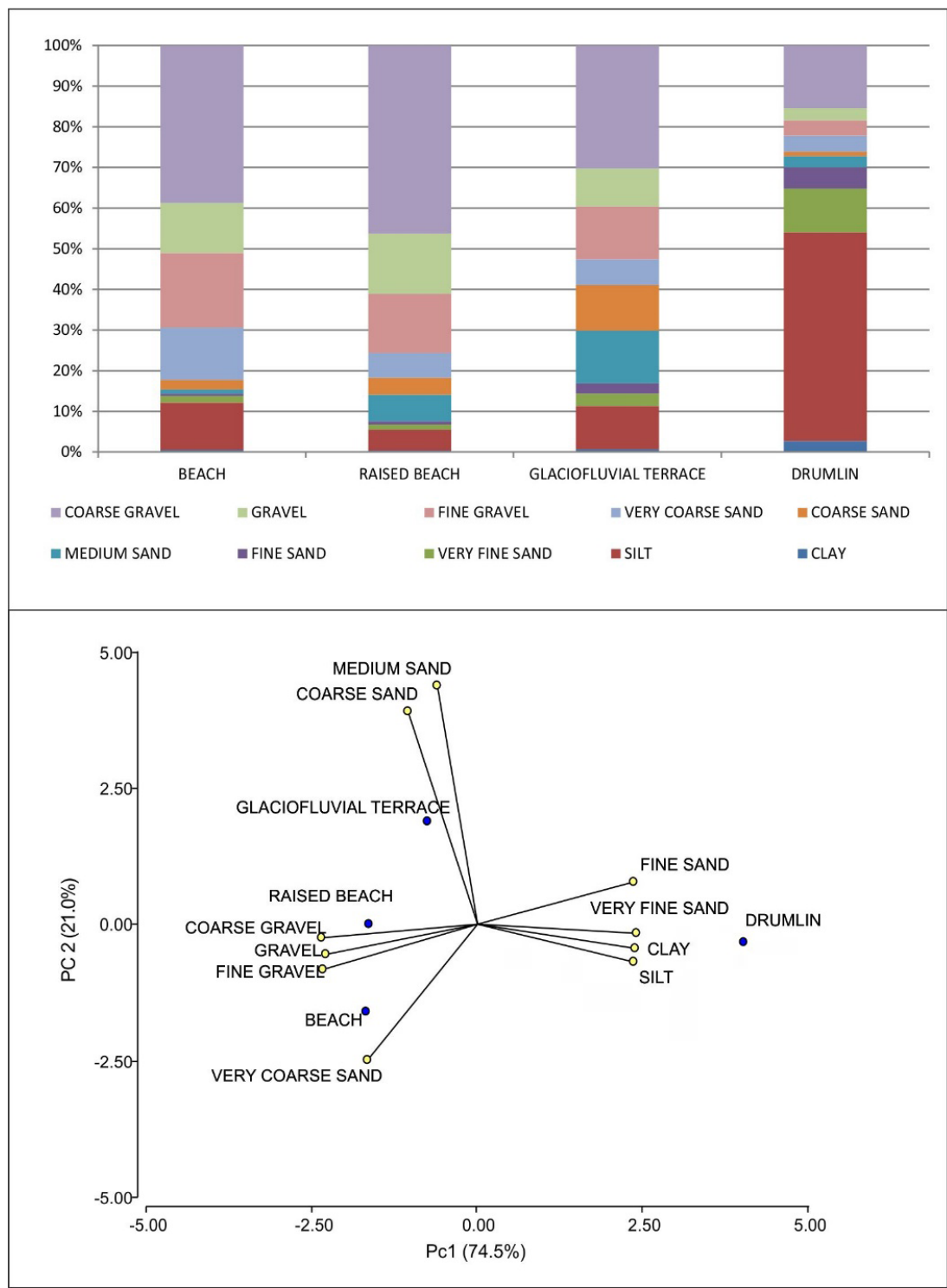

Figure 6. A. Grain-size analyses of sediments by landform (in percentage). D=Drumlin; $B=$ Raised beach; $T=$ Glaciofluvial terrace. $B$. Principal components analysis (PCA) showing the main two axes (PC1 and PC2) that explain together $95 \%$ of the variation of sediments for different landforms.

Littoral landforms are gravel raised beaches and the current ones. The first develop surrounding the glaciofluvial terraces and drumlins and connect both ends of the island (Fig. 4). Those landforms extent over 12 ha or $27 \%$ of the total surface. 
There are three raised beach levels developed up to the $5 \mathrm{~m}$ over the present beach berm. The sedimentary composition is different in grain-size proportions (Fig. 6). From the results of PCA, it is observed that drumlin was characterized by sediments with more presence of silt loam. The beach was defined with sandy loam while the glaciofluvial terrace and raised beach were characterized by sediments with loamy sand (Fig. 6B). While the raised beach at the foot of the western drumlin is mainly composed by gravel into a silty matrix with low content of sand, the others two raised beaches are gravelly-sand. A similar situation is observed in the $\mathrm{S}$ coast, where the raised beach developed near the drumlin is more gravelly than those located close to the glaciofluvial terraces which are mainly sandy. Different grain-size contents are related to the role of glacial landforms as sediment sources for beaches formation. Gravels are rounded and discoid. Sub-fossil fragments and whole individuals of marine shells could be found in most of the raised beaches. Considering their elevation above the present beach berm, three different levels of raised beaches could be found: The highest at 4-5 m, those in the middle at $3 \mathrm{~m}$ and the lowest at $1 \mathrm{~m}$. At any of them, present littoral processes occur. Beaches where the vegetation cover was removed by trampling or nesting, are eroded by deflation during strong winds in dry seasons. Middle to coarse gravel, boulders, most of them rounded, wood and shell fragments and solid waste are their components. The present beaches extend all around the island, 15-20 m towards the interior and occupying $25 \%$ of the total surface.

The island surface increases to the east due to glaciofluvial terrace and raised beaches developed between the drumlins, which are only remnants of the original landforms. The eastern drumlin is better preserved, so the island surface increases to the east, with rounded, convex-type hills located in its ends (Figs. 5A and C), while terraces domain the rest of the landscape. The glaciofluvial terrace presents a maximum elevation of $10 \mathrm{~m}$ a.s.1., a low slope percentage and a talus between glaciofluvial terraces and raised beaches, in general, lower than $1 \mathrm{~m}$ (Fig 5C). Figure $5 \mathrm{C}$ shows the island sector where the topography is more irregular and where the maximum elevation is reached (37 $\mathrm{m}$ a.s.1.). The high topographic step formed by the glaciofluvial terrace is also noticeable (Fig. 5C) and is also one of its distinctive relief features. The tour visit to the penguin colony performed by tourists is performed on this landform.

\subsection{Biogenic erosive features}

Specific erosive features are generated by the penguin displacement and nest building over unconsolidated and permeable sandy gravel sediments of the glaciofluvial terraces and raised beach and beach or into the gravelly-silt till of drumlins. Caves, bridges between caves, pedestals and trails were identified (Fig. 7). These erosive features are also enhanced by the cutting of vegetation by penguins to build their nests. 


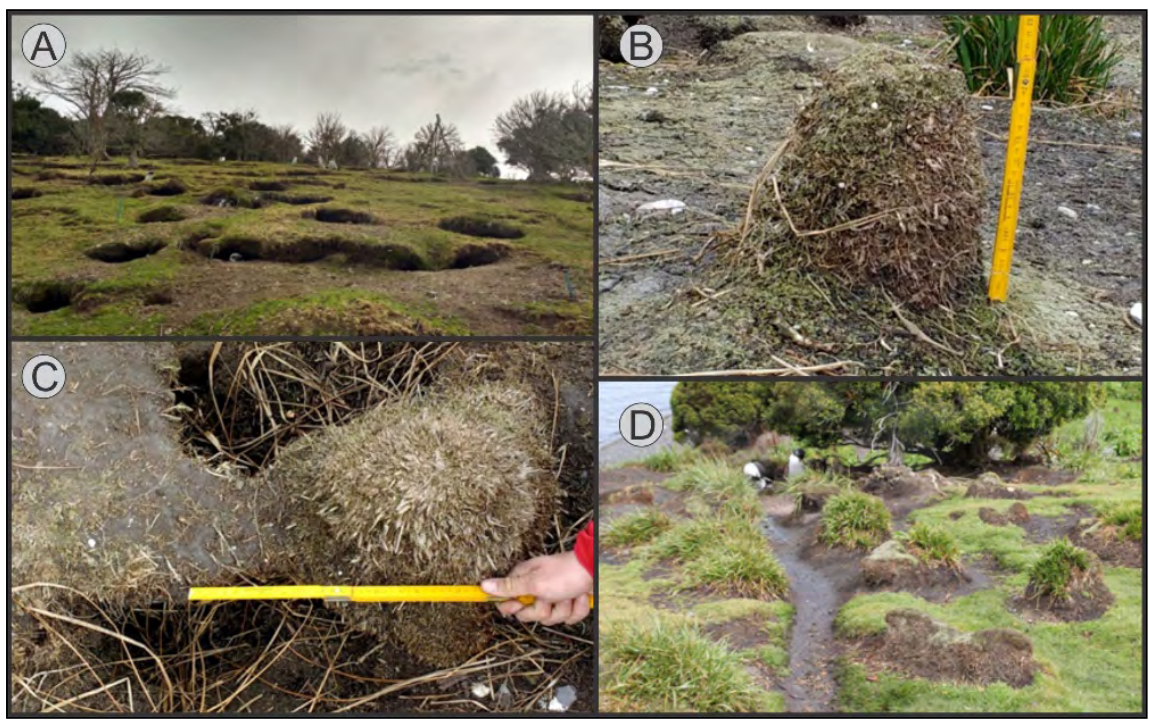

Figure 7. Biogenic erosive features originated by Magellanic penguin (Spheniscus magellanicus) in Martillo island. A) Caves (or burrow nests), B) Pedestal made in deteriorated Hierochloe redolens tuft, C) Bridge and D) Trail eroded over drumlin surface in the eastern cliff coast; tuft pedestals could also been observed.

\subsubsection{Caves}

Caves are cavities or holes of different shape, size and depth resulting from the digging of sediments (Fig. 7A). They are used as burrow-nests in each spring-summer season. The height $(\mathrm{X})$ of the cave entrance was similar when comparing among landforms $(F 2=1.1$; $p=0.34)$. By the contrast, the width $(\mathrm{Y})$ and the depth $(\mathrm{Z})$ of the caves were different between landforms $(F 2=8.62 ; p<0.0005$ and $F 2=10.78 ; p<0.0005$, respectively). The deepest nests $(Z)$ were recorded in caves dug on raised beach landforms $(p<0.5)$, while the width (Y) was only larger on the drumlin than at the raised beach $(p<0.5)$ (Table 1).

Table 1. Average and standard deviation (SD) of cave features as height of entrance $(X)$, width of entrance $(Y)$ and depth $(Z)$, by landform. Note: On beach landform, there were not caves.

\begin{tabular}{|c|c|c|c|c|}
\hline \multicolumn{2}{|c|}{} & Drumlin & Raised beach & Glaciofluvial terrace \\
\hline \multirow{2}{*}{$X(\mathrm{~cm})$} & Average \pm SD & $41.1 \pm 9.3$ & $38.4 \pm 10.4$ & $43.7 \pm 9.1$ \\
\cline { 2 - 5 } & Range & $22-60$ & $14-62$ & $25-54$ \\
\hline \multirow{2}{*}{$Y(\mathrm{~cm})$} & Average \pm SD & $24.4 \pm 5.6$ & $20.3 \pm 4.5$ & $23.7 \pm 5.8$ \\
\cline { 2 - 5 } & Range & $16-42$ & $9-32$ & $14-31$ \\
\hline \multirow{2}{*}{$Z(\mathrm{~cm})$} & Average \pm SD & $35.7 \pm 17.5$ & $52.9 \pm 24.9$ & $27.3 \pm 16.5$ \\
\cline { 2 - 5 } & Range & $13-110$ & $11-116$ & $8-57$ \\
\hline
\end{tabular}


The relationship between the width (Y) and height (X) of the mouth of the cave allows us to propose morphological types based on the proportionality between those variables. It varies from vertical and narrow rectangles to large horizontal and short ones. Caves dug for nesting purposes have relationships values in the range of $0.5 / 1$, in which the height duplicates the width, to $12 / 1$, in which the width is twelve times the height. In the first, the appearance of the mouth cave is like that of a vertical rectangle while in the second is like that of a large horizontal one. The more frequent values are relationships $1.5 / 1$ and $2 / 1$ in which the width is a bit bigger than the height and morphologies are rectangular.

\subsubsection{Bridges and cracks}

Bridges are defined as elongated soil or sediment remnants that connects two or more cave mouths o burrow nests (Fig. 7C). These are formed in high-density areas where caves are very close to one another. They are most frequently developed in drumlins due to the silty sediments with low content of clays promote cohesion and plasticity offering resistance to overweight or frequent trampling. The formation of cracks across them or around the connected caves indicates that instability has started and crashes could occur.

\subsubsection{Pedestals}

These are vertical columns made of sandy soils remnants or dry tuft vegetation. These were formed by the erosion of the surrounding terrains by intensive trampling. Vegetation pedestals formations are also related to the cutting of long leaves of Hierochloe redolens for burrows accommodation. More than $85 \%$ of the recorded pedestals are taller than $10 \mathrm{~cm}$ (Fig. 7B). They are located on the eastern drumlin and in the northern raised beach.

\subsubsection{Trails}

Trails are walkways without vegetation cover that connect the nests in the interior of the island with the beach, allowing access to the sea for feeding. Most of the recorded trails are wider than $10 \mathrm{~cm}$ and are covered by low grasses. This type of trail is built in raised beaches and glaciofluvial terraces. Those in drumlins are also wider than $10 \mathrm{~cm}$ and show the silty sediments (Figure 7D) that are eroded and transported by penguins feet or by runoff in the rainy or melt-snow seasons. Gullies formation originates along trails that connect terraces or raised beaches with the sea-shore.

\subsection{Bio-erosion}

Erosion on drumlins, glaciofluvial terraces and raised beaches has been promoted by the presence of ca 20,000 individuals of Magellanic penguin seasonally established in a small island with high relative relief and slopes, landforms of varied type of sediments and easy access from the sea to a vegetated interior. Drumlins and raised beaches are the most eroded landforms, mainly by caves and trails (Fig. 8). 


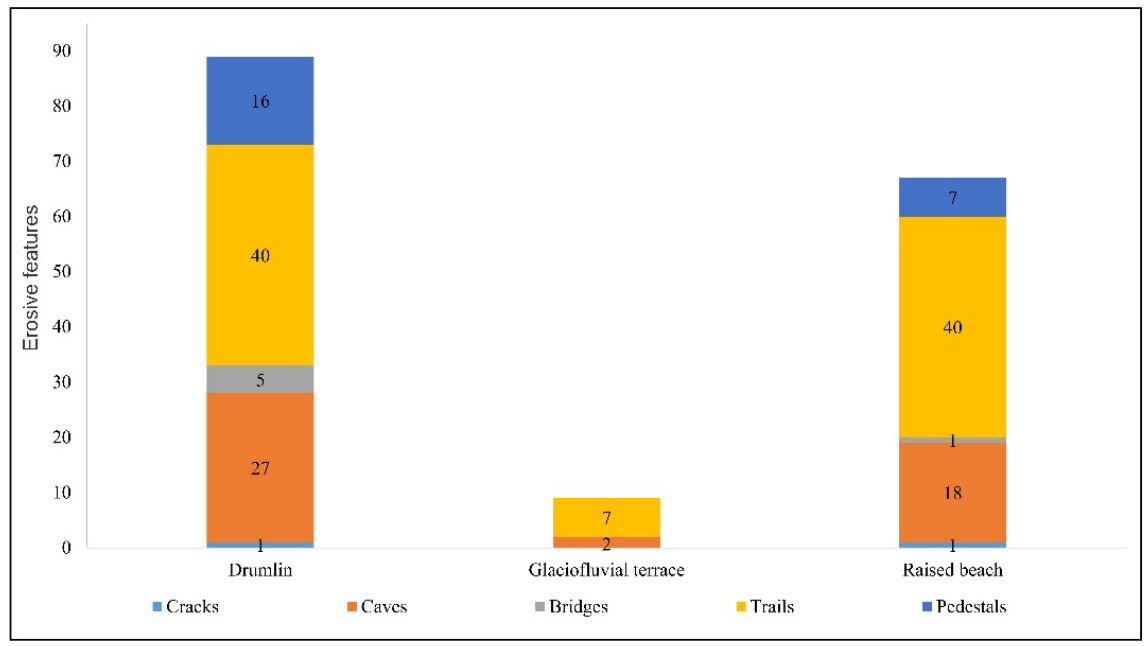

Figure 8. Erosive features frequency by landforms.

Caves are the erosive features that produce the most notorious changes on landforms and soils. Where caves and trails abound, the surface has the appearance of a "gruyere cheese", densely punched, with bare soils and exposed sediments, sometimes covered by hepatics or mosses as degradation signs. A similar aspect was described as "a mine-field" by Ercolano et al. (2016) in a Patagonian colony. In spite of that, the bio-erosion map shows the different percentages of erosion. The predominant erosion class is "middle", with between $30 \%$ to $50 \%$ of the surface affected by erosion (Fig. 9), mainly along the cliffs, in the convex summit of the eastern drumlin and in its $\mathrm{N}$ slope and gullies (Fig. 9).

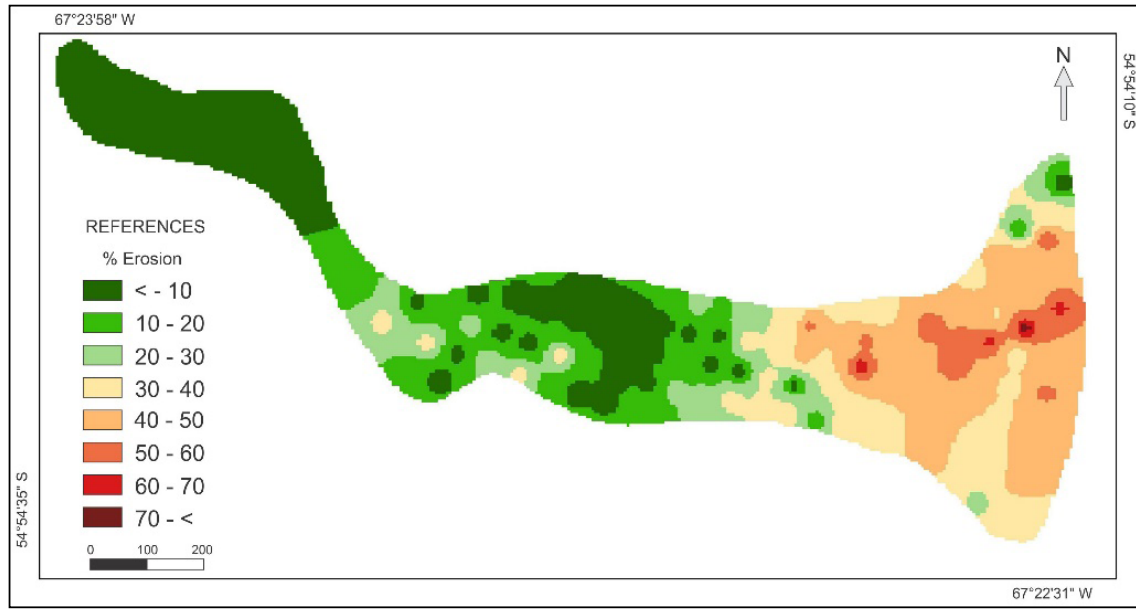

Figure 9. Bio-erosion categories in Martillo Island, Beagle Channel, caused by the transit and nesting of a Magellanic penguin (Spheniscus magellanicus) colony. 
Low-middle erosion and low erosion categories $(<10$ to $30 \%)$ are the more extensive all over the island concentrated in the central and western; by the contrary, high-middle erosion $(50$ to $70<$ ) is focused in the eastern sector. Also, the low-middle erosion category can be found in some parts of the centre and S coast. The sediments dug by penguins are quickly remobilized by the wind action and runoff in the inland and by wave action along the coast.

This indirect process causes especially strong effects in the steepest areas, such as at the $\mathrm{E}$ end of the island, where erosion rates are higher next to the penguin paths.

Aeolian action is more intense in the areas with higher sediment nets as in the NE sector, where penguin action had been removed the vegetation cover. By the contrary, is reduced in the forest areas due to vegetation protection.

The erosion percentage in Martillo Island increased with the average nest density $(\beta=0.003 . \mathrm{SD}=0.0004, t=5.7, p<0.0001)$ and the slope $(\beta=0.09 . \mathrm{SD}=0.03, t=3.5$, $p<0.0001)$, while it was not different between loamy sand and silt loam sediments $(\beta=0.077, \mathrm{SD}=0.17, t=0.46, p=0.65)$. This model accounted for $17.5 \%$ of variation in the erosion percentage and it did not exhibit overdispersion $(\hat{c}<1)$.

\section{Discussion}

The morphological impact of animals over landforms and processes is not frequently analysed in the geomorphic literature. Although the importance of burrowing animals of all sizes generating a particularly intense biotic creep on the steep slopes of sandy material was already mentioned by Tricart (1977). Excavator habits of birds, rodents and mammals were remarked as one of the important bioerosion features in soils (Butler, 1995). Different actions of animals, as burrowing, trampling, and loading causes geomorphological imprint in landscapes (Hall and Lamont, 2003). Among them, beaver (Castor sp.) is pointed out as one of the most important biogenic agents due to the strong impact that it produces in fluvial systems (Johnston et al., 1987; Coronato et al., 2003). Instead, the incidence of birds in sediment re-distribution or as geomorphic processes trigger is less taking into account in landscape modelling analyses. Santos González et al. (2006) showed the first observations of erosive features as a consequence of the Magellanic penguin colony established in Martillo Island. Ercolano et al. (2016) proposed the erosive effect of the same species along the semiarid Patagonian coast pointing out deflation in dunes fields and sandy terrains as the main problems. Both studies focused on the effect of the bird's habits on the geomorphic aspects of the landscape, although landforms, climate and vegetation are different in both places. By the contrary, in most of the papers related to Magellanic penguin habits, the physical environment and its dynamics were analyzed as a conditioner of ecological behaviour patterns (Stokes and Dee Boersma, 1991, 1998; García-Borboroglu et al., 2002; Rebstock et al., 2015).

The varied relief and sediment type of the Martillo Island was not an impediment for the Magellanic penguin colony to establish itself. According to Hall and Lamont (2003), the animals prepare sediments for transport by geomorphic agents, changing slope stability conditions, promoting chemical and physical pedoturbation and increasing 
soil compaction. Penguins remove sediments that are transported by runoff, aeolian and marine action, increasing erosion rates. Penguins also remove vegetation cover as grasses, tussocks and small bushes, increasing instability in many landforms, so its indirect action could be as important as its direct action.

The higher value of nest density (101-300 nests/ha, Fig. 2) is found in the eastern drumlin landform, where the relative relief to the present beach is the highest. In the same sector are the highest slope values, between 8 and 15\% (Fig. 3). In addition, this area is part of the eastern drumlin, composed of till, being a very cohesive deposit. Drumlin morphology and sediment type do not have the best qualities for nest excavation and access but this landform is covered by woods that provide protection against the dominant SW winds. Repair conditions given by the slope degree and woods of this sector could be one of the causes for the first colony settlement and where the high nest density values are been recorded for a throughout time (Scioscia et al., 2017). In contrast, nest density values are low in sectors almost flat and bushy, where the slope is also low, sandy sediments are easy to dig, the access to the sea is favourable due to distance and slope but are exposed to rigorous wind conditions.

Nesting habits in caves and sea access through continually used trails bring on the major erosive impacts in this glacially and littoral sculptured island. Burrow-nests excavation into drumlins could demand greater energy consumption than those excavated into raised beaches or terraces, but the cohesivity of silt avoid nests collapses, at least before the bridges formed. Those excavations located in the drumlin summit or in their slopes with middle to high values are less threatened by floods by surface runoff or snow-melting than those placed on the raised beaches or terraces. This could be another cause for high nest density value in the eastern drumlin.

It seems that the sedimentary composition and slope values of the glacial landform offers a better environmental condition for nest perdurability than the other landforms, although they have the best sea access conditions. The removal of sediments also causes significant indirect actions, since the penguin acts as an initial factor that triggers other processes. The erosive processes are more active in the steepest areas, as other authors have observed for other species (Hall and Lamont, 2003). This is the case of the eastern drumlin cliff and the northeastern raised-beach where most of the marine sediments (up to 1-2 meters) has been removed and till is appearing.

\section{Conclusion}

The Martillo Island is similar in genesis and geomorphic dynamics than others in the Beagle Channel but is the only affected by bio-erosion caused by marine birds. Since five decades ago it is the seasonal nesting habitat of Spheniscus magellanicus. Geographical location, relief and its component materials make it distinctive to other patagonian colonies. Herein, the erosive action of birds, do trigger deflation plumes, holes, collapses, gully deepening and soil erosion by vegetation cover destroy occurs.

Littoral runoff and mass wasting are the main present modelling process that sculptured the island relief. Bio-erosion produced by penguins must be considered as 
an important process at micro-scale dynamics, mainly in the eastern ending. Spheniscus magellanicus must be considered as a biogenic geomorphic agent due to their capacity to create landforms or features quite different from those created by the traditional geomorphic agents.

Erosion by nest digging and trails use could expand to the rest of the island; it would depend on changes on the nest density. How bio-erosion values would affect the ecological behaviour of the penguin's colony is a matter of biological studies been performed by a part of the authors.

\section{Acknowledgements}

Estancia Harberton allowed us to perform this survey. PiraTour Travel agency provided the transfers to the island. Lola Boffo, Manuel Bulacio, Samanta Dodino, Ignacio Magneres and Margarita Schiavini help us in the field surveys. I. Magneres performed the grain-size analyses at CADIC laboratory. CADIC provides logistic for lab and field tasks. Roxana Diaz reviewed the language style. Funds were provided by Wildlife Conservation Society, PUE-CONICET 2016-0077; PICT 2014-1870.

\section{References}

Benn, D.I, Evans, D.J.A. 1996. The interpretation and classification of subglacially deformed materials. Quaternary Science Reviews 15, 23-52. https://doi.org/10.1016/02773791(95)00082-8.

Boswall J, MacIver D. 1975. The Magellanic penguin Spheniscus magellanicus. In: B. Stonehouse (Ed.), The Biology of penguins, Macmillan, Londres. pp. 271-305. https://doi. org/10.1007/978-1-349-02270-0_11.

Borchard, P., Eldridge, D.J. 2011. The geomorphic signature of bare-nosed wombats (Vombatus ursinus) and cattle (Bos taurus) in an agricultural riparian ecosystem. Geomorphology, 130 (3-4), 365-373. https://doi.org/10.1016/j.geomorph.2011.04.021.

Bujalesky, G., Coronato, A., Roig, C., Rabassa, J. 2004. Holocene differential tectonic movements along the argentine sector of the Beagle Channel (Tierra del Fuego) inferred from marine palaeoenvironments. Bollettino de Geofísica Teórica Ed applicata 45 (2), 235-238.

Bujalesky, G., Coronato, A., Acevedo, R., Rabassa, J. 2008. El Canal Beagle. Un paisaje marino esculpido por el hielo. In: CSIGA (Eds.), Sitios de Interés Geológico de la República Argentina, Los geólogos nos cuentan. SEGEMAR, Anales 46, Tomo II-Sur, Buenos Aires. pp. 849-864.

Butler, D.R. 1995. Zoogeomorphology: animals as geomorphic agents. Cambridge University Press. New York. https://doi.org/10.1017/CBO9780511529900.

Coronato, A.,Escobar,J., Mallea,C., Roig,C.,Lizarralde,M.2003.Características geomorfológicas de ríos de montaña colonizados por Castor canadensis en Tierra del Fuego, Argentina. Ecología Austral 13, 1526. Buenos Aires.

Coronato, A., Coronato, F., Mazzoni, E., Vázquez, M. 2008. Physical Geography of Patagonia and Tierra del Fuego. In: J. Rabassa (Ed.), Late Cenozoic of Patagonia and Tierra del Fuego. Development in Quaternary Sciences, Volume 11 (3), 13-56. Elsevier, Rotterdam. https:// doi.org/10.1016/S1571-0866(07)10003-8. 
Di Rienzo, J.A., Casanoves, F., Balzarini, M.G., Gonzalez, L., Tablada, M., Robledo, C.W. 2009. Infostat. FCA Universidad Nacional de Córdoba, Argentina.

Eldridge, D.J., Koen, T.B., Killgore, A., Huang, N., Whitford, W.G. 2012. Animal foraging as a mechanism for sediment movement and soil nutrient development: evidence from the semi-arid Australian woodlands and the Chihuahuan Desert. Geomorphology 157, 131-141. https://doi.org/10.1016/j.geomorph.2011.04.041.

Ercolano, B., Cruz, I., Marderwald, G. 2016. Impacto de los pingüinos patagónicos (Spheniscus magellanicus) en la dinámica geomorfológica de Punta Entrada (Patagonia austral, Argentina). Cuaternario y Geomorfología 30 (3-4), 29-48. https://doi.org/10.17735/cyg.v30i3-4.51463.

Gandini, P., Frere, E., Boersma, P.D. 1996 Status and conservation of Magellanic penguins Spheniscus magellanicus in Patagonia, Argentina. Bird Conservation International 6, $307-$ 316. https://doi.org/10.1017/S0959270900001787.

García-Borboroglu, P., Yorio, P., Boersma, P., Del Valle, H., Bertellotti, M. 2002. Habitat use and breeding distribution of Magellanic Penguins in northern San Jorge Gulf, Patagonia, Argentina. Auck 119, 233-239. https://doi.org/10.1093/auk/119.1.233.

Gordillo, S., Coronato, A., Rabassa, J. 1992. Late Quaternary evolution of a subantarctic paleofjord, Tierra del Fuego. Quaternary Science Reviews 12 (10), 889-912. https://doi. org/10.1016/0277-3791(93)90027-J

Hall, K., Lamont, N. 2003. Zoogeomorphology in the Alpine: some observations on abioticbiotic interactions. Geomorphology 55 (1-4), 219-234. https://doi.org/10.1016/S0169$555 \mathrm{X}(03) 00141-7$.

Haussmann N.S. 2017. Soil movement by burrowing mammals: A review comparing excavation size and rate to body mass of excavators. Progress in Physical Geography, 41 (1), 29-45. https://doi.org/10.1177/0309133316662569.

Isla, F., Bujalesky, G., Coronato, A. 1999. Procesos estuarinos en el Canal Beagle, Tierra del Fuego. Revista de la Asociación Geológica Argentina, 54 (4), 307-318.

Johnston, C. Naiman, R. 1987. Boundary dynamics at the aquatic-terrestrial interface: the influence of beaver and geomorphology. Landscape Ecology 1, 47-57. https://doi.org/10.1007/ BF02275265.

Jones, C.G. 2012. Ecosystem engineers and geomorphological signatures in landscapes. Geomorphology, 157-158: 75-87. https://doi.org/10.1016/j.geomorph.2011.04.039.

Moore, D. 1983. Flora of Tierra del Fuego. Anthony Nelson Publisher, England. 396 pp.

R Development Core Team, 2009 R: A language and environment for statistical computing. R Foundation for Statistical Computing, Vienna, Austria

Rabassa, J., Heusser, C., Stuckenrath, R. 1986. New Data on Holocene Sea Transgression in the Beagle Channel: Tierra del Fuego, Argentina. Quaternary of South America and Antarctic Peninsula 4, 291-309.

Rabassa, J., Serrat, D., Marti, C., Coronato, A. 1990. Internal Structure of drumlins in Gable Island, Beagle Channel, Tierra del Fuego, Argentina. LUNDQUA Report 32, 3-5. Lund University.

Rabassa, J., Coronato, A., Bujalesky, G., Roig, C., Salemme, M., Meglioli, A., Heuser, C., Gordillo, S., Borromei, A., Quatrocchio, M. 2000. Quaternary of Tierra del Fuego, Southernmost South America: un updated review. Quaternary International 68-71, 217-240. https://doi. org/10.1016/S1040-6182(00)00046-X.

Rabassa, J., Coronato, A., Gordillo S, Candel MS, Martínez MA. 2009. Paleoambientes litorales durante la Trasgresion Marina Holocena en bahía Lapataia, Canal Beagle, Parque Nacional Tierra del Fuego, Argentina. Revista de la Asociación Geológica Argentina 65 (4), 648-659.

Raya Rey, A., Rosciano, N., Liljesthröm, M., Sáenz Samaniego, R., Schiavini, A. 2014. Species-specific population trends detected for penguins, gulls and cormorants over 20 years in sub-Antarctic Fuegian Archipelago. Polar Biology, 1-18. https://doi.org/10.1007/s00300-014-1526-6. 
Santos González, J., Coronato, A., Ghys, M., Schiavini, A. 2006. Procesos erosivos generados por una colonia de pingüino magallánico (Spheniscus magellanicus), Isla Martillo, Canal Beagle, Argentina. VI Jornadas Nacionales de Geografía Física, Resúmenes: 18. Río Gallegos.

Schiavini, A., Raya Rey, A. 2001. Aves y mamíferos marinos en Tierra del Fuego: Estado de situación, interacción con actividades humanas y recomendaciones para su manejo. Fundación Patagonia Natural, Puerto Madryn.

Schiavini, A., Yorio, P. 1995. Distribution and abundance of seabird colonies in the Argentine sector of the Beagle Channel, Tierra del Fuego. Marine Ornithology 23, 39-46.

Schiavini, A., Yorio, P., Gandini, P., Raya Rey, A., Boersma, P.D. 2005. Los pingüinos de las costas argentinas: estado poblacional y conservación. El Hornero 20, 5-23.

Scioscia, G., Coronato, A., Quiroga, D., Schiavini, A., Pütz, K., Raya Rey, A. 2017. How much do penguins take care of their habitat? Population regulation in Magellanic penguin, Spheniscus magellanicus, at Martillo Island, Beagle Channel, Tierra del Fuego. Ornithological Congress of the Americas. XVII RAO/XXIV CBO/XCV AFO. Puerto Iguazú, Argentina.

Scolaro, A. 1980. El Pingüino de Magallanes (Spheniscus magellanicus) VI. Dinámica de la población de juveniles. Hist. Nat., Mendoza, Arg. 1 (25), 173-176.

Stockes, D.L., Boersma, P. 1991. Effects of substrate on distribution of Magellanic Penguin (Spheniscus magellanicus) burrows. The Auck 108, 923-933.

Stockes, D.L., Boersma, P. 1998. Nest-sites characteristics and reproductive success in Magellanic Penguin (Spheniscus magellanicus). The Auck 115 (1), 34-49. https://doi. org/10.2307/4089109.

Thomas, L., Buckland, S.T., Rexstad, E.A., Laake, J.L., Strindberg, S., Hedley, S.L., Bishop, J.R.B., Marques, T.A., Burnham, K.P. 2010. Distance software: design and analysis of surveys for estimating population size. Journal of Applied Ecology 47, 5-14. https://doi. org/10.1111/j.1365-2664.2009.01737.x.

Tricart, J. 1977. Précis de Géomophologie. Tome II. Géomorphologie Dynamique Générale. Paris, S.E.D.E.S.

Williams, T.D. 1995. The penguins. Oxford, USA: Oxford University Press. 